\title{
Estimation of the load of cyclic organochlorines in North Sea zooplankton
}

\author{
M. Krause ${ }^{1} \&$ R. Knickmeyer ${ }^{2}$ \\ ${ }^{1}$ Universität Hamburg, Institut für Allgemeine Botanik; Ohnhorststraße 18, \\ $D-W-2000$ Hamburg 52, Federal Republic of Germany \\ ${ }^{2}$ Universität Hamburg, Institut für Biochemie und Lebensmittelchemie; Martin-Luther- \\ King-Platz 8, D-W-2000 Hamburg 13, Federal Republic of Germany
}

\begin{abstract}
During a North Sea survey in late spring 1986, zooplankton biomass (g dry weight $/ \mathrm{m}^{2}$ ) as well as pollutant concentrations in zooplankton ( $\mathrm{ng} / \mathrm{g}$ dry weight) were determined at 127 stations. On the basis of these data, the load of several cyclic organochlorines in zooplankton $\left(\mathrm{ng} / \mathrm{m}^{2}\right)$ was estimated. It appeared that the highest loads of these pollutants were incorporated in the large zooplankton stocks of the northern and central North Sea, north of $56^{\circ} \mathrm{N}$, whereas the highest concentrations were found in zooplankton of the southern North Sea. An explanation for the accumulation of pollutants in sediments as well as in benthos organisms of the central and northern North Sea as found by several authors is discussed in connection with the assumption of a considerably high vertical flux of organic material in these areas. The calculation of total zooplankton content in the North Sea during the late spring survey amounted to about 5 million tons dry weight. This biomass was estimated to contain about $2.6 \mathrm{t} \mathrm{PCBs}$, $19.3 \mathrm{~kg}$ p.p'-DDE, $12 \mathrm{~kg} \tau-\mathrm{HCH}$, $6.4 \mathrm{~kg} \mathrm{HCB}$ und $5.6 \mathrm{~kg} \alpha-\mathrm{HCH}$. These results agree with those on other compartments of the North Sea ecosystem (benthos, fish) found in recent literature. The estimated annual turnover of PCBs in zooplankton (15.2 $t$ ) is of the same order of magnitude as the estimated amount transported yearly into the North Sea by rivers and the atmosphere $(6-13 \mathrm{t})$.
\end{abstract}

\section{INTRODUCTION}

Within the framework of the interdisciplinary ZISCH-Project (Circulation and Pollutant Transfer in the North Sea), a number of scientists investigated the fate of contaminants in the North Sea ecosystem. The work included determination of the concentrations of several pollutants in different ecosystem compartments with the aim of setting up a budget and modelling pollutant transfer in the North Sea. In this context, the present publication joins together two data sets from a North Sea survey in spring (May 2-June 6, 1986) for the purpose of estimating the load of selected cyclic organochlorines in the zooplankton. Results are given for zooplankton biomass ( $g$ dry weight $/ \mathrm{m}^{2}$ ) as well as the concentrations ( $\mathrm{ng} / \mathrm{g}$ zooplankton dry weight) of the following organochlorines: 24 PCBcongeners (sPCB), p. $\mathrm{p}^{\prime}-\mathrm{DDE}, \mathrm{HCB}, \alpha-\mathrm{HCH}$ and $\tau-\mathrm{HCH}$ ). 


\section{MATERIAL AND METHODS}

\section{Zooplankton biomass}

Sampling method: The zooplankton samples were generally collected with the "Meßhai", a multi-closing net system that allows a subdivision of the water column into five vertical layers by means of oblique hauls. During bad weather conditions, an alternative multi-closing-net was sometimes used to perform vertical hauls from aboard the drifting vessel. In shallow coastal areas as well as over the Dogger Bank, the simple WP-2-Net was used. All nets had mesh sizes of $200 \mu \mathrm{m}$.

During May/June 1986, samples were collected at 127 stations over the entire North Sea (Fig. 1). At 73 stations the water column was sampled with the "Meßhai". The filtration of approximately $3700 \mathrm{~m}^{3}$ water resulted in 315 samples from different depth ranges. At 28 stations the vertical multi-closing net was used giving 112 samples, while at 26 very shallow stations samples were taken with the WP-2-Net.

Wet weight estimates: The wet weights of the samples were determined on land with a micro-balance (Pag Oerlikon AG, Zürich) using the preserved material. The samples were washed on a piece of gauze. The water was carefully sucked off so that the organisms remained undamaged for subsequent taxonomic determination. Large medusae which now and then occurred in the samples were removed, since their high water contents would falsify the results of the wet weight estimates. The results of the measurements were related to the flow meter data of the "Meßhai", giving wet-weight per $\mathrm{m}^{3}$. Finally, this data material was converted to dry weight by means of a conversion factor given by Cushing et al. (1958).

\section{Concentrations of cyclic organochlorines in plankton}

Collection of samples: Samples were taken at 127 stations over the entire North Sea from 2 May-13 June 1986. The plankton was obtained using a WP-2-Net or a multi-closing net ("Meßhai"), with mesh-sizes of $200 \mu \mathrm{m}$.

Treatment of samples: Mixed hauls of phyto- and zooplankton were treated with three drops of chloroform per litre seawater to separate the animals from the algae. The anaesthetized zooplankton could then be removed from the bottom of the filtering jar with a pipette $5 \mathrm{~min}$ after the treatment. Only zooplankton or phytoplankton could be used from these stations because of deficiency in biomass.

Zooplankton samples were filtered to dryness over a Büchner funnel. Filters were then immediately deep frozen at $-25^{\circ} \mathrm{C}$ in glass tubes. The gelatinous colonies of the alga Phaeocystis globosa from continental coastal waters were frozen in sea water in a 250-ml screw-top laboratory bottle.

After transferring the samples to the laboratory on land, the filters with the zooplankton were lyophilized in their glass tubes. The lyophilizates were mixed with $3 \mathrm{~g}$ sea sand and $0.5 \mathrm{~g}$ anhydrous $\mathrm{Na}_{2} \mathrm{SO}_{4}$ for every gram of dried plankton, and ground to a homogenous powder in an agate mortar. After thawing to room temperature, samples with $P$. globosa colonies were transferred into a round bottom flask and lyophilized. Sea sand $(50 \mathrm{~g})$ was added to the lyophilizates and the flasks were shaken in a mechanical shaker for $2 \mathrm{~h}$ in order to obtain a fine powder. 




Fig. 1. Station grid of the ZISCH-North Sea Survey (02 May - 13 June, 1986) 
The resulting powder mixtures were transferred into a folder filter and extracted in a Soxhlet with $\mathrm{n}$-hexane for $8 \mathrm{~h}$. The extracts were reduced nearly to dryness in a rotary evaporator (temperature $<40^{\circ} \mathrm{C}$ ), and, subsequently, the extracted lipids were air-dried at $65^{\circ} \mathrm{C}$ for $4 \mathrm{~h}$ in an oven. The weights of the extracted lipids were determined gravimetrically.

The extracted dissolved lipids $(10-55 \mathrm{mg})$ in $1 \mathrm{ml} \mathrm{n}$-hexane were quantitatively transferred to a micro liquid-solid chromatography column (LSC), filled with $2.9 \mathrm{~g}$ basic $\mathrm{Al}_{2} \mathrm{O}_{3}$ and $0.1 \mathrm{~g} \mathrm{Na}_{2} \mathrm{SO}_{4}$ on top to separate interfering substances. As an eluent, $23 \mathrm{ml} \mathrm{n}$ hexane was used.

The eluted fraction contained the organochlorines under investigation. This solution was reduced to $1 \mathrm{ml}$ in a rotary evaporator, shaken with $1 \mathrm{ml} \mathrm{H}_{2} \mathrm{SO}_{4}$ in order to destroy substances disturbing the subsequent analytical procedure and transferred onto the same type of LSC filled with $1 \mathrm{~g} \mathrm{SiO}_{2}$ and $0.1 \mathrm{~g} \mathrm{Na}_{2} \mathrm{SO}_{4}$ on top for further cleaning and separation.

$6 \mathrm{ml} \mathrm{n}$-hexane were used as eluent for fraction 1, containing the sPCB, HCB and p, p'DDE. An additional $17 \mathrm{ml}$-hexane was used to obtain fraction 2, containing a- $\mathrm{HCH}$ and Lindane. $\varepsilon$-hexachlorocyclohexane $(\varepsilon-\mathrm{HCH})$ was added to both fractions as an internal standard. The two $\mathrm{n}$-hexane fractions were reduced to $0.5 \mathrm{ml}$, then dissolved in $2 \mathrm{ml}$ cyclohexane and reduced in a rotary evaporator to remove the n-hexane three consecutive times. The final volumes were $0.1-1 \mathrm{ml}$ cyclohexane solution, depending on the expected concentrations of the compounds under investigation.

These samples were analysed by temperature-programmed capillary gas chromatography (Carlo Erba HRGC 5300 equipped with a 63Ni-ECD, Merck-Hitachi 2000 integrator). The standard contained 24 individual PCB components, $\alpha-\mathrm{HCH}$, Lindane, $H C B, p, p^{\prime}-D D E$ and $\varepsilon-H C H$. The 24 congeners used are a selection of the main PCB components expected, as was introduced by Duinker et al. (1983). The system was recalibrated after 20 samples. The areas of the sample peaks were compared to the areas of corresponding peaks in the standard solution.

In the following, SPCB refers to the respective sums of the selected 24 PCB isomers (Fig. 2). These 24 isomers represent about $50 \%$ of the ECD response.

\section{RESULTS}

Before showing results regarding an estimation of the load of cyclic organochlorines in zooplankton, a separate representation of the data sets used will be given.

\section{Zooplankton biomass ( $\mathrm{g} \mathrm{dw} / \mathrm{m}^{2}$ )}

The data on biomass, which have been depth-integrated to the sea bottom (but maximally up to $150 \mathrm{~m}$ depth), are presented in Figure 3. The distribution patterns are outlined as iso-lines. According to these, large zooplankton stocks were found primarily in the northern and central North Sea (north of $56^{\circ} \mathrm{N}$ ), except for small concentration maxima off the Firth of Forth, the Channel mouth and the Rhine estuary. This zone of high biomass extended in a broad left-turning trace from the Shetland Islands to the mouth of the Skagerrak and was mainly formed by the large copepod Calanus finmar- 


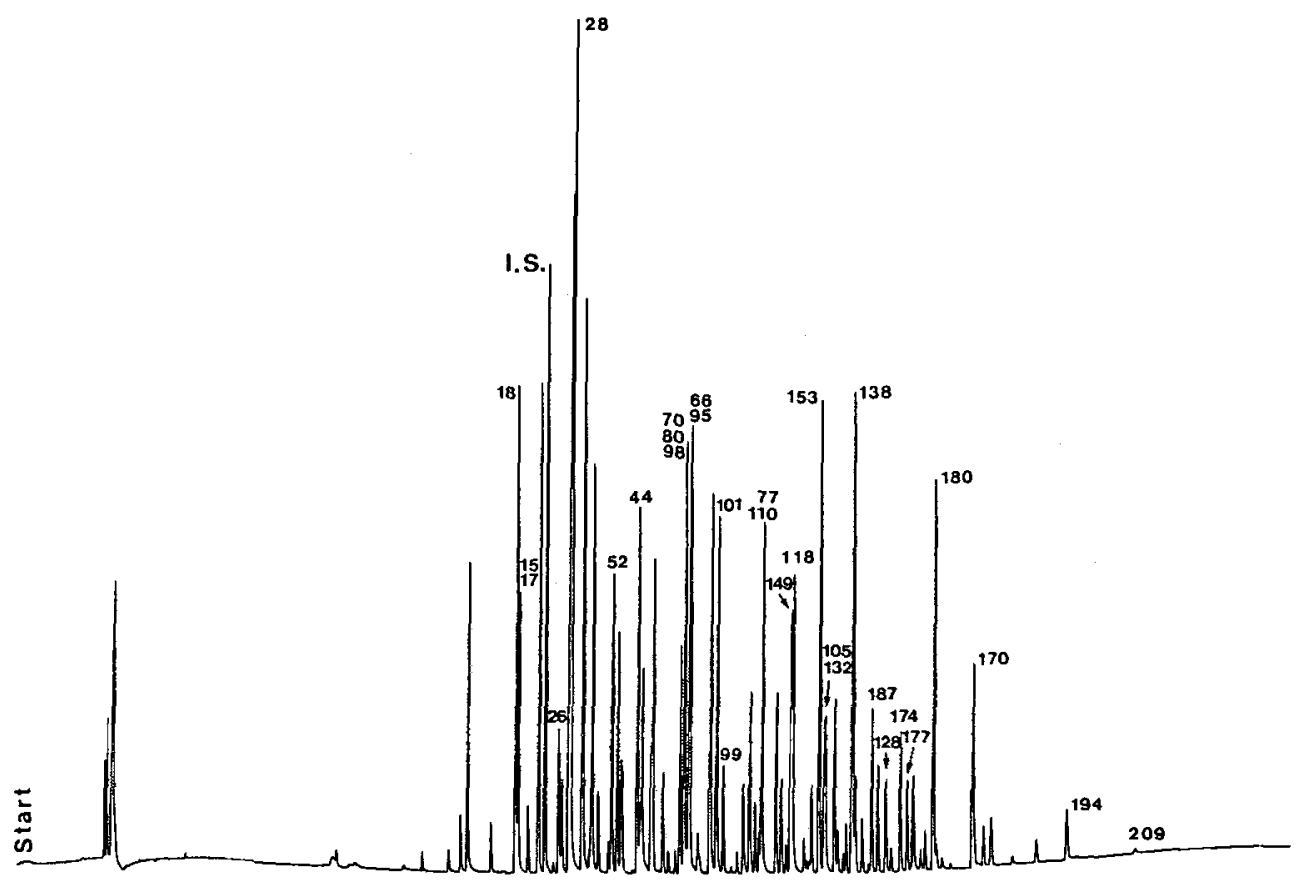

Fig. 2. Example of a chromatogram of zooplankton from the SE 54-CB fused silica column, reconstructed using a PCB mixture (clophen A30/A40/A50/A60 [4.0/1.0/0.8/1.2]). Components detected in zooplankton (numbering of components according to Ballschmiter \& Zell, 1980); for coeluting components quantization was done on the basis of the first (upper) component. I.S. = internal standard $\in-\mathrm{HCH}$

chicus, which - as we know - drifts in spring from its overwintering grounds in the deep sea of the North Atlantic into the shallow North Sea with the currents.

A further centre of high biomass extended off the Danish coast proceeding from the estuaries of Weser and Elbe up to the mouth of the Skagerrak, where it fused with the stocks of the Skagerrak. Here, as well as in the rest of the southern North Sea, small copepods like Temora longicornis and Acartia spp. dominated.

Relatively low zooplankton-biomasses were found in extensive parts of the southern North Sea, near the Danish coast, in the Norwegian Trench, and west of the Orkneys and Shetlands as well as in the centre of the northern North Sea.

A clearer picture of zooplankton distribution emerged, when the mathematical influence of depth was eliminated by dividing the data of depth-integrated biomasses by the corresponding water depths (Fig. 4). Then it can be stated that, irrespective of waterdepth, the biggest zooplankton-stocks occur in the northern and central North Sea. They are distributed in a spiraloid pattern in the area north of $56^{\circ} \mathrm{N}$. The hydrographic and biological causes of these distribution patterns are discussed by Krause \& Martens (1990). 




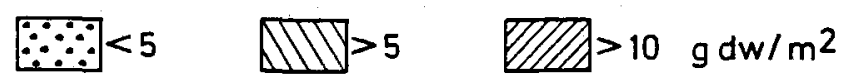

Fig. 3. ZISCH North Sea Survey, 02 May - 13 June 1986. Isogram of zooplankton dry weight (mg/m²) 


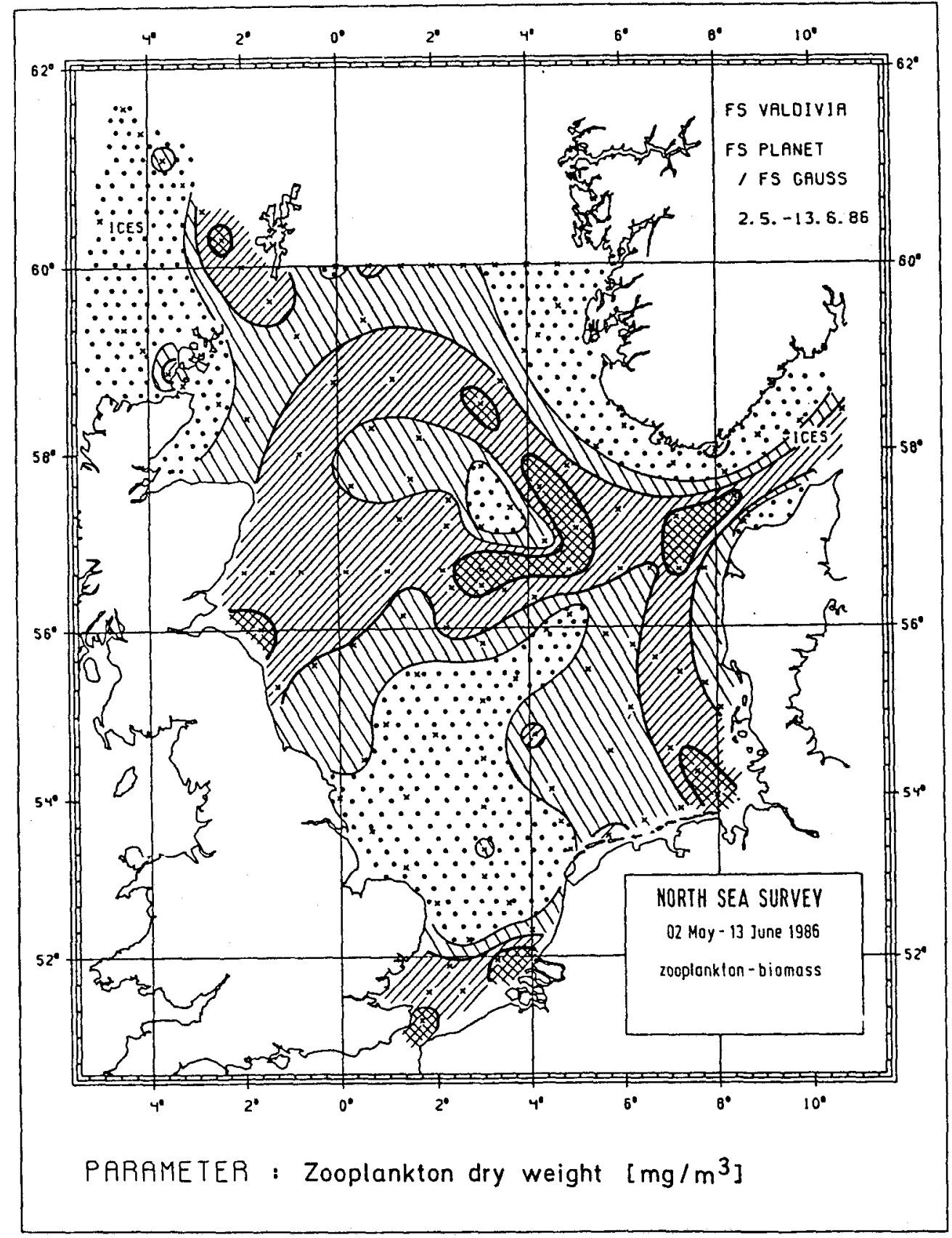

$\because \because<>50 \quad \triangle I I>50 \quad>\mathbb{Z}>>100 \quad>200 \mathrm{mg} \mathrm{dw} / \mathrm{m}^{3}$

Fig. 4. ZISCH North Sea Survey, 02 May - 13 June 1986. Isogram of zooplankton dry weight $\left(\mathrm{mg} / \mathrm{m}^{3}\right)$ 


\section{Concentrations of cyclic organochlorines in zooplankton (ng/g dw)}

Knickmeyer \& Steinhart (1989a) carried out their measurements of cyclic organochlorines in mixed zooplankton samples on $n$-hexane extracted lipid fraction. The concentrations of sPCB, p, $\mathrm{p}^{\prime}-\mathrm{DDE}, \mathrm{HCB}, \tau-\mathrm{HCH}$ and $\alpha-\mathrm{HCH}$ in plankton are represented by histograms over the entire North Sea (Figs 5-9).

All diagrams indicate that the concentrations of pollutants in plankton decreased from the continental coast to the open sea in the North, as we would expect, based on the distribution patterns of dissolved organochlorines in the waters of the North Sea (e.g. Gaul \& Ziebarth, 1983; Carlson, 1986). The highest values were found in the Phaeocystisdominated samples just off the Dutch and German coasts, where the concentrations of organochlorines were higher by a factor 5 than those of the neighbouring zooplanktondominated samples. Knickmeyer (1990a) assumed that this enrichment originated mostly from suspended particulate matter, which is abundant in coastal areas, and may be adsorbed onto the gelatinous surface of the algae. In the present publication, these algaedominated stations were not taken into consideration. Nevertheless, the T. longicornisdominated samples in the southern North Sea had clearly higher concentrations of cyclic organochlorines than those of C. finmarchicus-dominated samples in the areas north of $56^{\circ} \mathrm{N}$. Knickmeyer (1989) and Knickmeyer \& Steinhart (1989a) gave a detailed presentation and discussion of the data.

\section{The load of cyclic organochlorines in North Sea zooplankton}

The data sets described above on the concentrations of certain organochlorines in the zooplankton may be a foundation for further toxicological investigations. Nevertheless, by multiplying the pollutant concentrations (ng/g zooplankton dw) with the depthintegrated values for biomass $\left(g \mathrm{dw} / \mathrm{m}^{2}\right)$ of the corresponding stations, we obtain information on the part of zooplankton in pollutant transfer. In this way, finally, a first estimation of the total load of the pollutants in North Sea zooplankton is possible, making use of data obtained from the ZISCH-station grid.

These results are depicted as histograms over the entire North Sea. In particular, they represent the quantities of SPCB (Fig. 10), HCB (Fig. 11), p,p'-DDE (Fig. 12), $\tau-\mathrm{HCH}$ (Fig. 13) and $\alpha-\mathrm{HCH}$ (Fig. 14) stored in zooplankton found at each station under one square metre of sea water. The histograms indicate that, as a rule, distinctly greater quantities of organochlorines were incorporated in the zooplankton biomass north of $56^{\circ} \mathrm{N}$. In contrast, in the southern North Sea the pollutant depots in zooplankton were relatively small. Exceptions were the Firth of Forth and the areas at the mouths of the estuaries of Thames, Rhine and Elbe, where larger pollutant depots in zooplankton were found.

Finally, the total zooplankton dry weight in the North Sea and its content of the measured pollutants were determined using both data sets (Table 1). According to this, during the North Sea survey in spring ' 86 almost 5 million tons of zooplankton (dw) were present, based on an area of $575000 \mathrm{~km}^{2}$ (Carlson, 1986). The "Rat von Sachverständigen" (1980) specified an annual production of herbivorous zooplankton in the North Sea of $50 \mathrm{~g} \mathrm{dw} / \mathrm{m}^{2}$; i.e. almost 29 million tons. Thus, the zooplankton stock we found during the North Sea survey in spring ' 86 would have amounted to $17-18 \%$ or a factor of 5.8 of the annual production. 


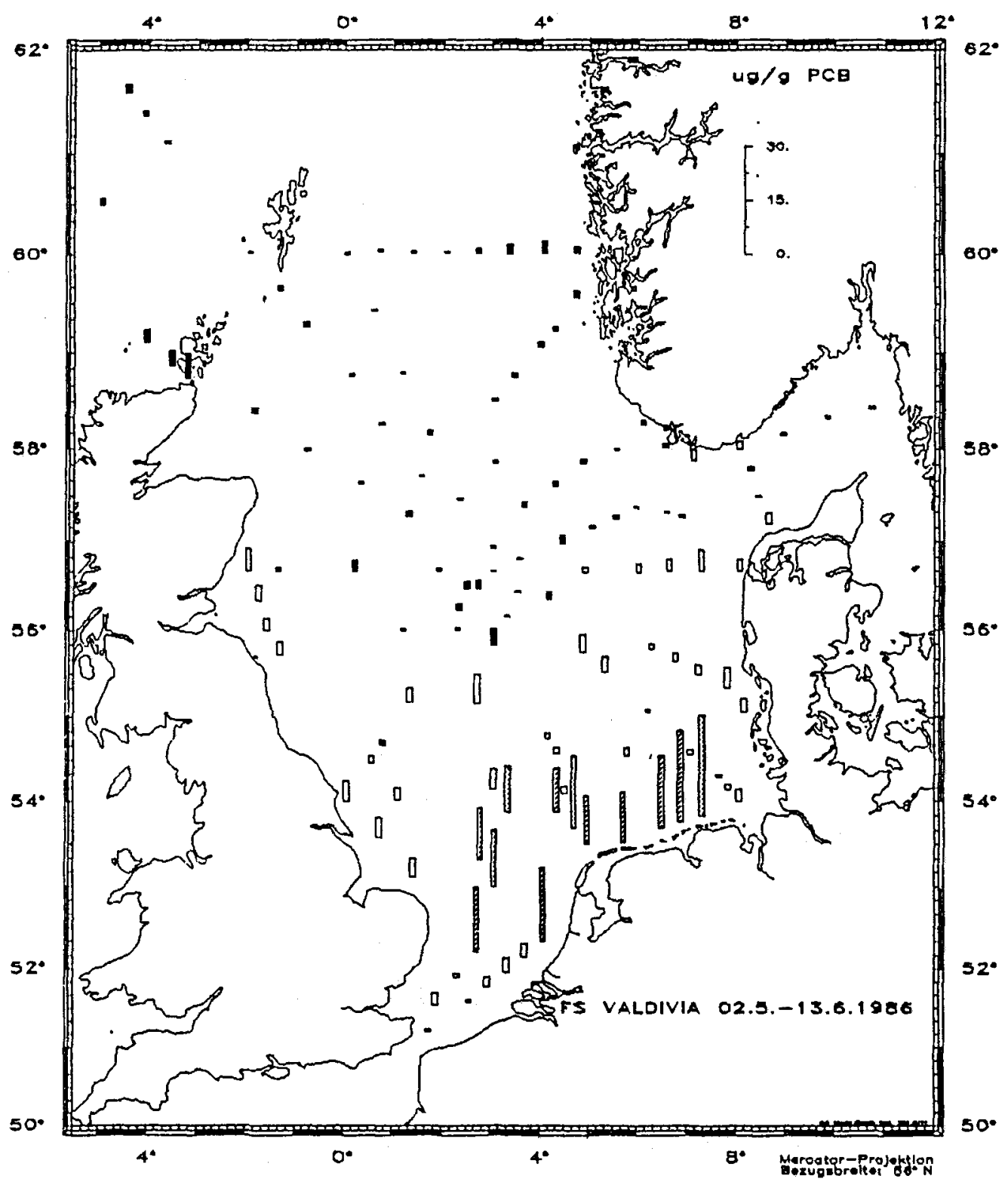

Fig. 5. Concentrations of SPCB (sum of 24 congeners) in plankton of the North Sea. $\square$ samples dominated by Calanus finmarchicus; $\square$ samples dominated by Temora longicornis; samples dominated by Phaeocystis globosa. The height of each symbol indicates concentration in $\mu \mathrm{g}$ $\mathrm{sPCB} \times \mathrm{g}^{-1} \mathrm{n}$-hexane extractable lipids, measured by the scale bar at top right of the chart (from Knickmeyer \& Steinhart, 1989a) 


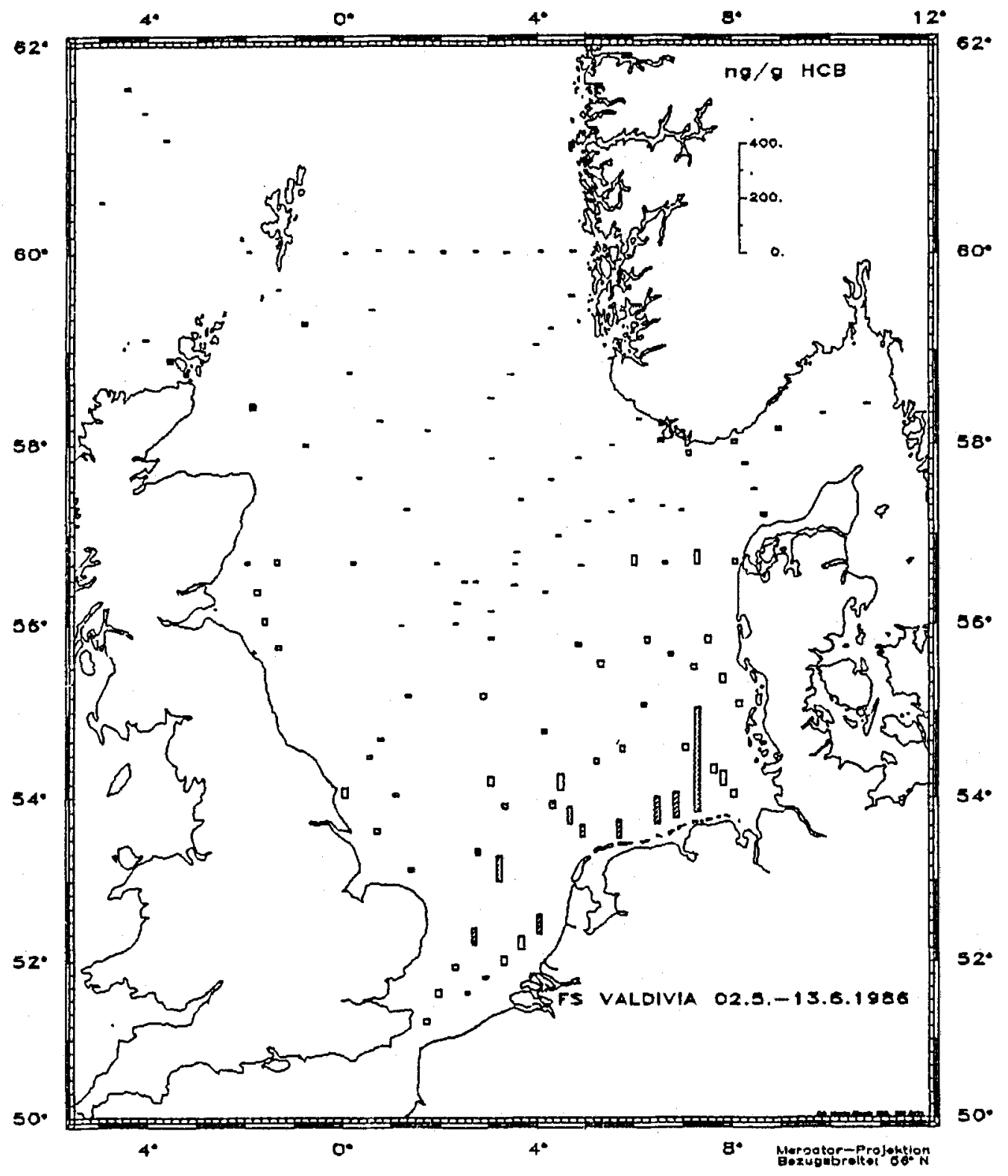

Fig. 6. Concentrations of HCB in plankton of the North Sea. $\square$ samples dominated by Calanus finmarchicus; $\square$ samples dominated by Temora longicornis; 留 samples dominated by Phaeocystis globosa. Concentrations: ng $\mathrm{HCB} \times \mathrm{g}^{-1} \mathrm{n}$-hexane extractable lipids, measured by scale bar, top right (from Knickmeyer \& Steinhart, 1989a) 


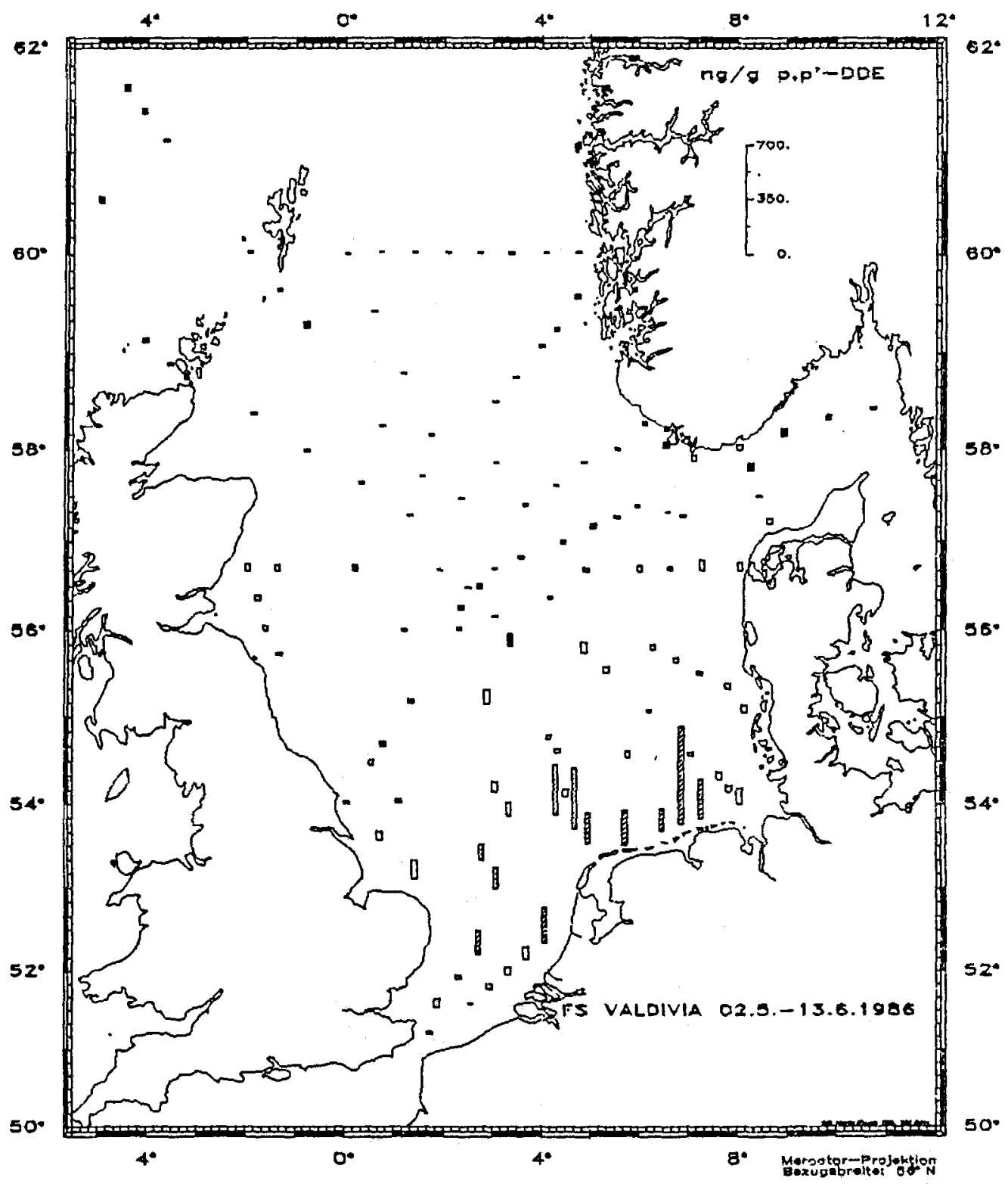

Fig. 7. Concentrations of p,p'-DDE in plankton of the North Sea. finmarchicus; $\square$ samples dominated by Temora longicornis; samples dominated by Phaeocystis globosa. Concentrations: ng p, $\mathrm{p}^{\prime}-\mathrm{DDE} \times \mathrm{g}^{-1} \mathrm{n}$-hexane extractable lipids (from Knickmeyer \& Steinhart, 1989a) 




Fig. 8. Concentrations of Lindane $(\tau-\mathrm{HCH})$ in plankton of the North Sea. $\square$ samples dominated by Calanus finmarchicus; $\square$ samples dominated by Temora longicornis; samples dominated by Phaeocystis globosa. Concentrations: ng Lindane $\times \mathrm{g}^{-1} \mathrm{n}$-hexane extractable lipids (from Knickmeyer \& Steinhart, 1989a) 


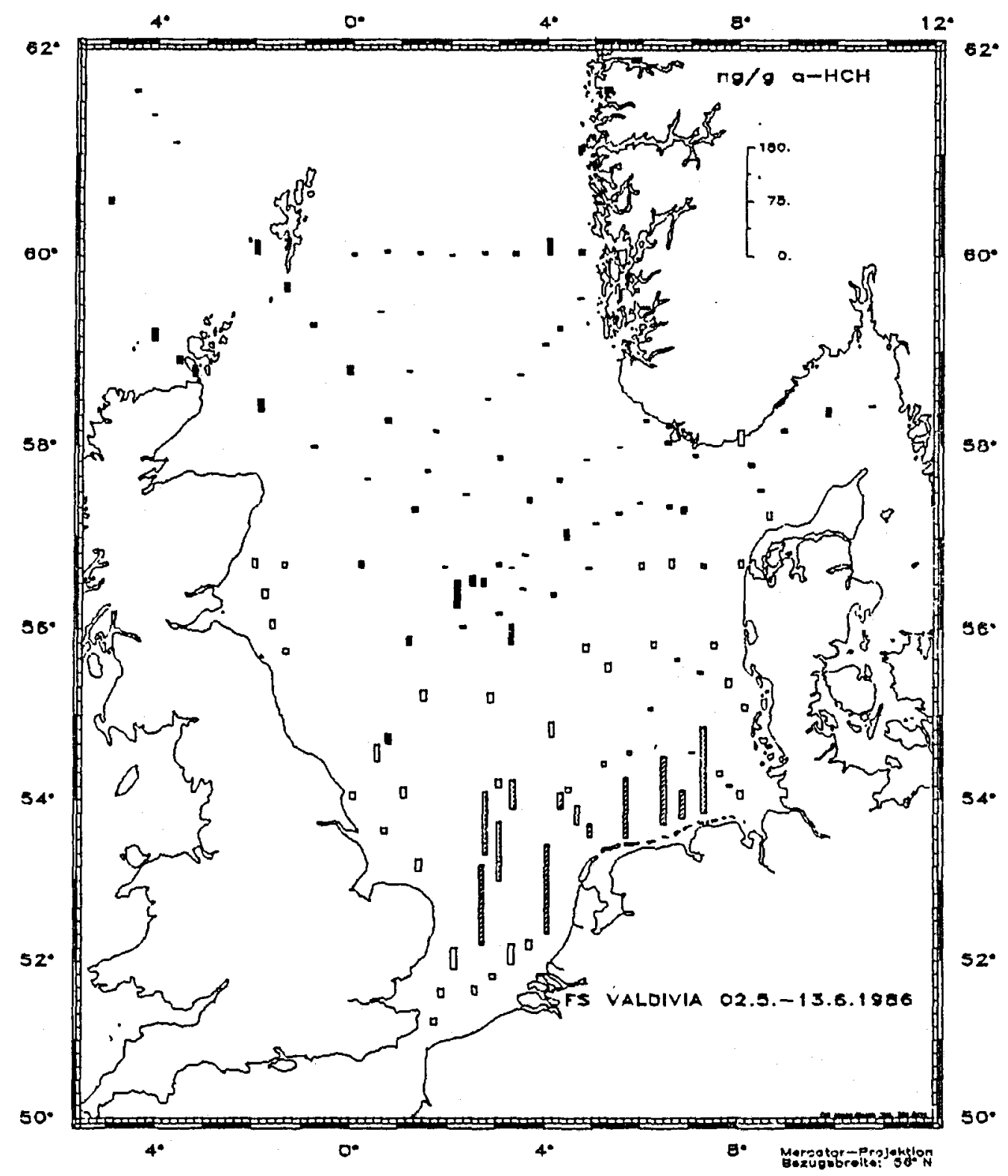

Fig. 9. Concentrations of $\alpha-\mathrm{HCH}$ in plankton of the North Sea. finmarchicus; $\square$ samples dominated by Temora longicornis; 国 samples dominated by Phaeocystis globosa. Concentrations: $\mathrm{ng} \alpha-\mathrm{HCH} \times \mathrm{g}^{-1} \mathrm{n}$-hexane extractable lipids, measured against scale bar, top right (from Knickmeyer \& Steinhart, 1989a) 


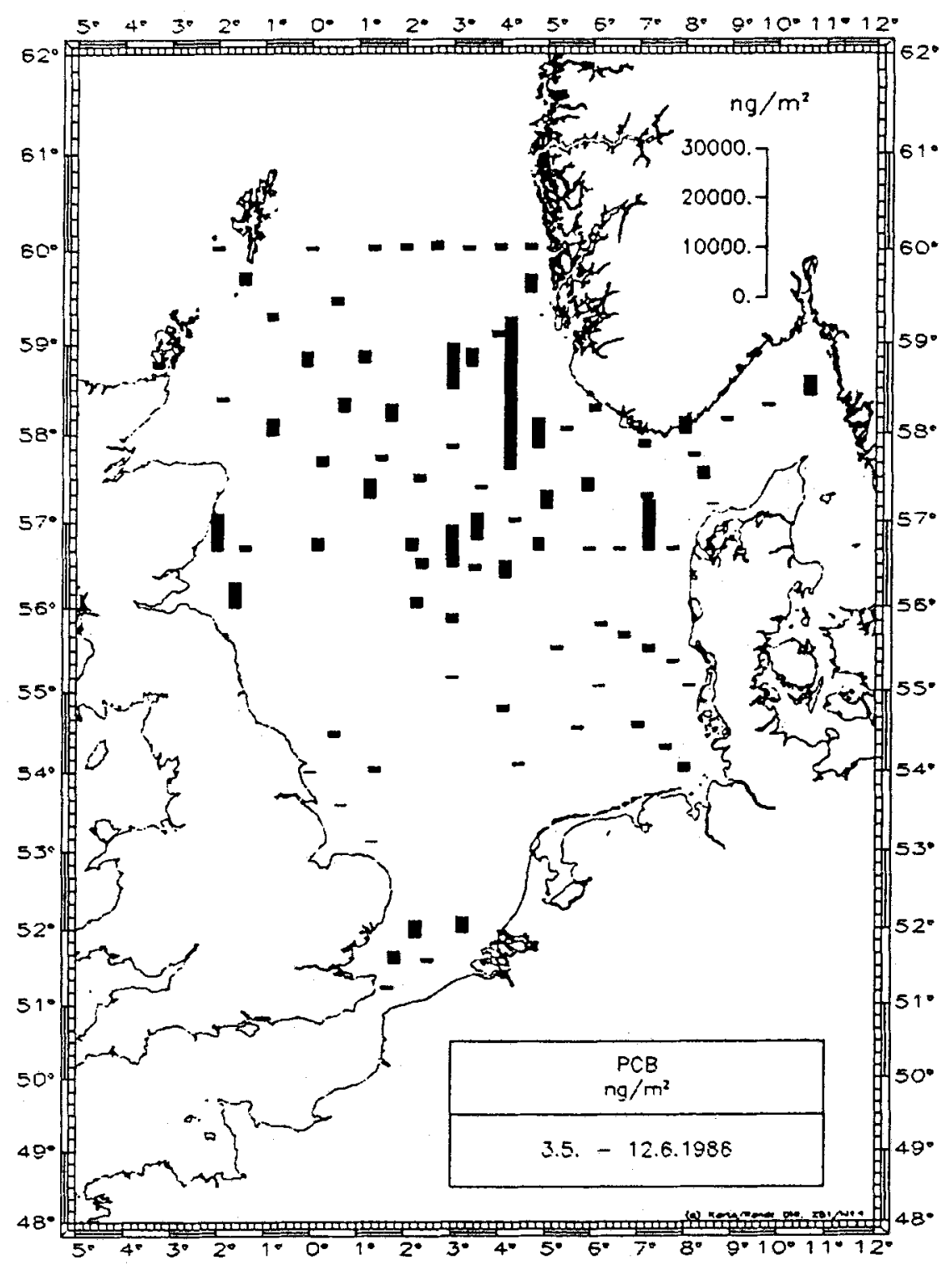

Source: ZISCH, Subproject G4/G8

MUDAB (Meeresumwelt-Datenbank) UBA-UMPLIS/DHI

Fig. 10. The load of SPCB (sum of 24 congeners) in zooplankton during the ZISCH-North Sea Survey (02 May - 13 June, 1986). The height of each symbol indicates the quantity of the pollutant (ng $\times \mathrm{m}^{-2}$ ) measured by the scale bar at top right of the chart 


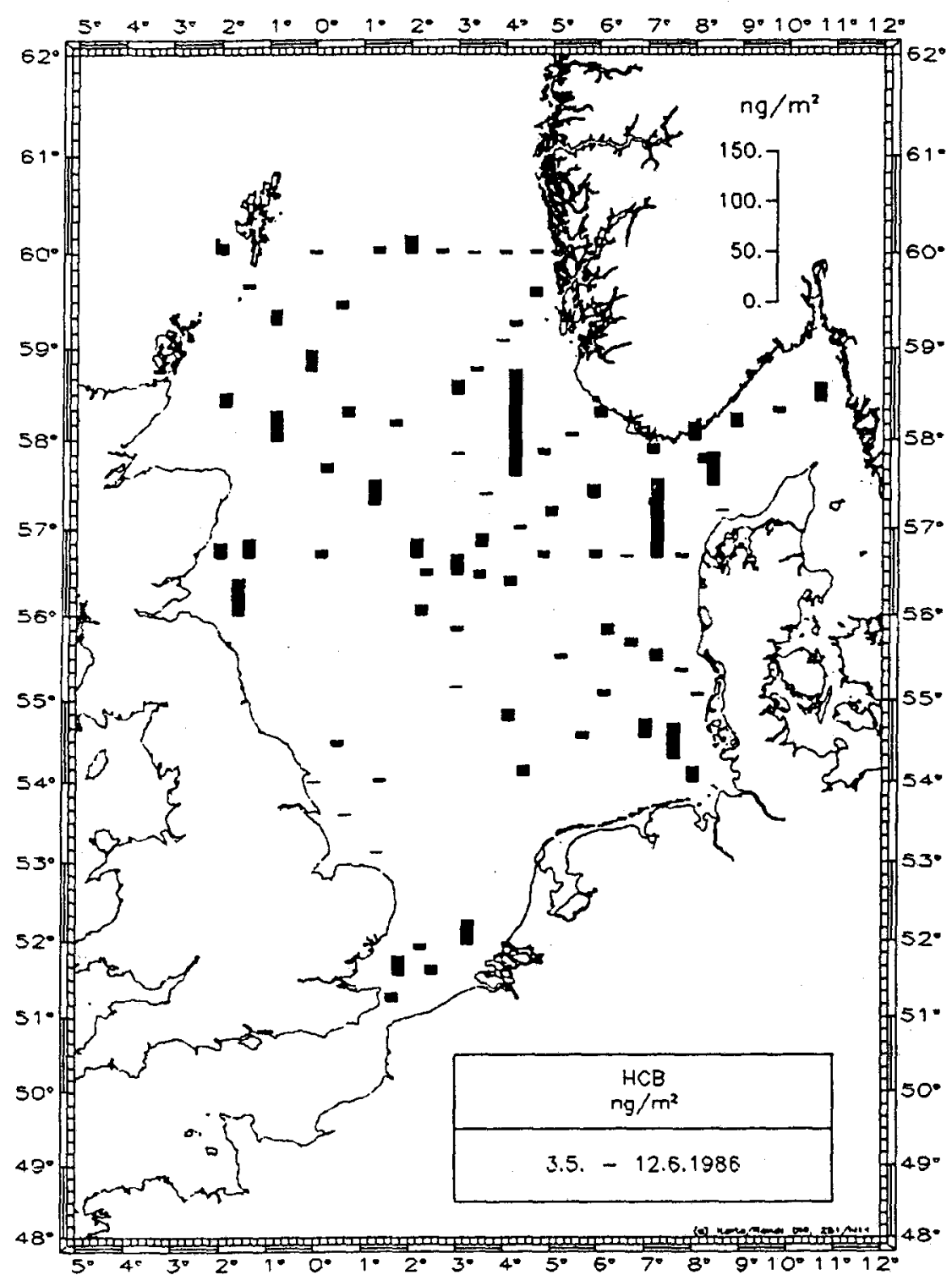

Source: ZISCH, Subproject G4/G8

MUDAB (Meeresumwelt-Datenbank) UBA-UMPLIS/DHI

Fig. 11. The load of HCB in zooplankton during the ZISCH-North Sea Survey 102 May - 13 June, 1986). The height of each symbol indicates the quantity of the pollutant $\left(\mathrm{ng} \times \mathrm{m}^{-2}\right.$ ) measured by the scale bar at top right of the chart 




Source: ZISCH, Subproject G4/G8

MUDAB (Meeresumwelt-Datenbank) UBA-UMPLIS/DHI

Fig. 12. The load of p,p'-DDE in zooplankton during the ZISCH-North Sea Survey (02 May - 13 June, 1986). The height of each symbol indicates the quantity of the pollutant ( $\left.\mathrm{ng} \times \mathrm{m}^{-2}\right)$ measured by the scale bar at top right of the chart 




Source: ZISCH, Subproject G4/G8

MUDAB (Meeresumwelt-Datenbank) UBA-UMPLIS/DHI

Fig. 13. The load of $\gamma-\mathrm{HCH}$ in zooplankton during the ZISCH-North Sea Survey 102 May - 13 June, 1986). The height of each symbol indicates the quantity of the pollutant (ng $\times \mathrm{m}^{-2}$ ) measured by the scale bar at top right of the chart 


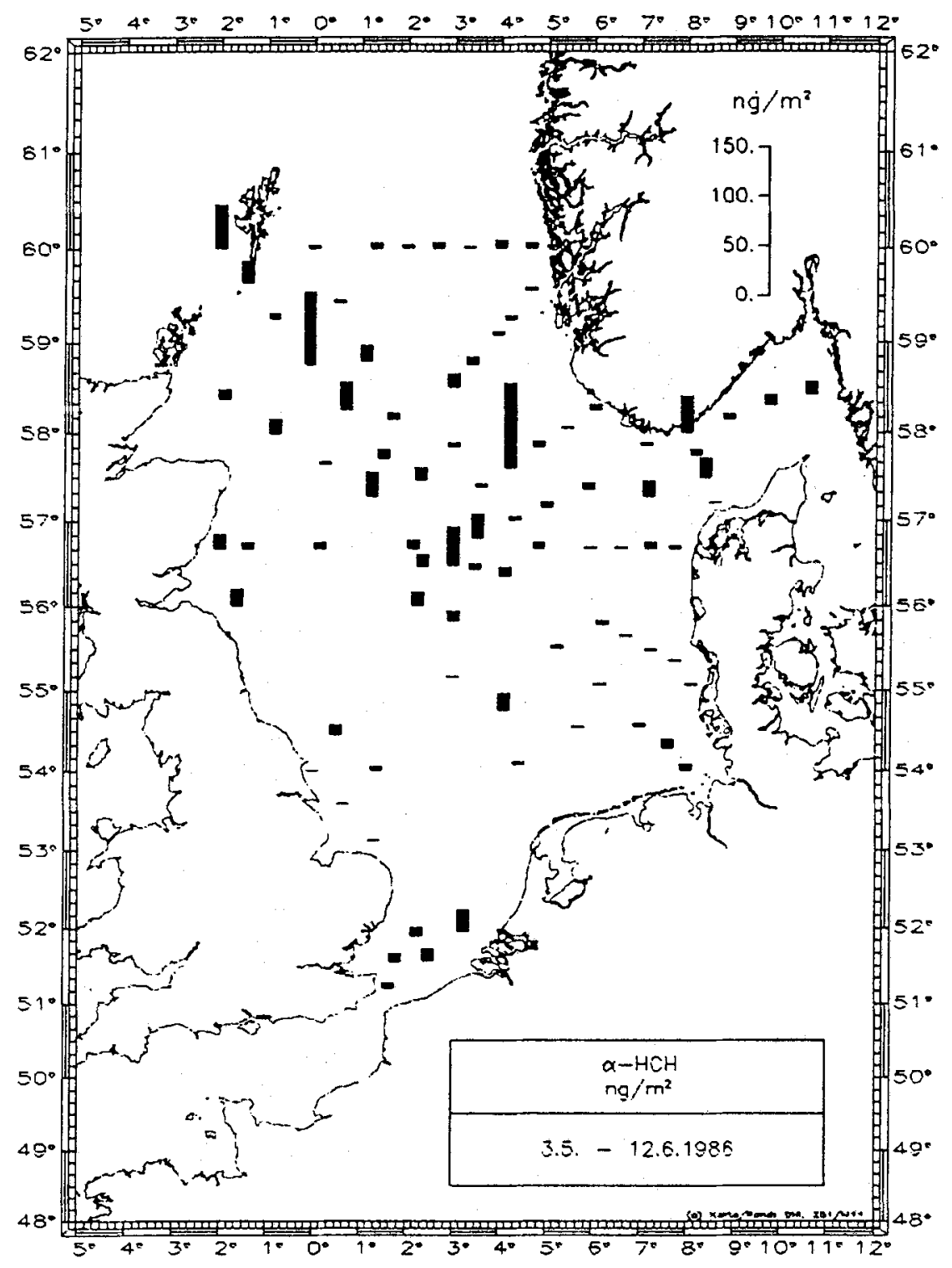

Source: ZISCH, Subproject G4/G8

MUDAB (Meeresumwelt-Datenbank) UBA-UMPLIS/DHI

Fig. 14. The load of $\alpha-\mathrm{HCH}$ in zooplankton during the ZISCH-North Sea Survey (02 May - 13 June, 1986). The height of each symbol indicates the quantity of the pollutant $\left(\mathrm{ng} \times \mathrm{m}^{-2}\right)$ measured by the scale bar at top right of the chart 
Table 1. Estimated quantities of total zooplankton (tons dry weight) in the North Sea during the ZISCH-Survey (02 May-13 June, 1986) as well as of its incorporated pollutants (sPCB, HCB, p,p'$\mathrm{DDE}, \alpha-\mathrm{HCH}, \tau-\mathrm{HCH})$ together with an estimate of the annual turnover of these substances in zooplankton. The calculation of the annual zooplankton production was based on the statements of the "Rat von Sachverständigen" (1980)

\begin{tabular}{|lccc|}
\hline & $\begin{array}{c}\text { Stations } \\
(\mathrm{N})\end{array}$ & $\begin{array}{c}\text { Total amount } \\
(\mathrm{t})\end{array}$ & $\begin{array}{c}\text { Annual } \\
\text { production/turn over } \\
(\mathrm{t})\end{array}$ \\
\hline Zooplankton (dw) & 127 & 4962521.6 & 28750000.0 \\
sPCB & 87 & $1.3042(2.6)$ & $7.5641(15.2)$ \\
$\mathrm{HCB}$ & 84 & 0.0064 & 0.0373 \\
p.p $\mathrm{p}^{\prime}-\mathrm{DDE}$ & 85 & 0.0193 & 0.1118 \\
$\alpha-\mathrm{HCH}$ & 87 & 0.0056 & 0.0327 \\
$\tau-\mathrm{HCH}$ & 87 & 0.0120 & 0.0694 \\
\hline
\end{tabular}

With 1.3 tons, the sPCB (24 PCB-isomers) represented by far the greatest proportion of cyclic organochlorines in the North Sea zooplankton. The following amounts were estimated for the other measured pollutants: $\mathrm{HCB}=6.4 \mathrm{~kg}, \mathrm{DDE}=19.3 \mathrm{~kg}, \alpha-\mathrm{HCH}=$ $5.6 \mathrm{~kg}$ and $\mathrm{\tau}-\mathrm{HCH}=12.0 \mathrm{~kg}$.

\section{DISCUSSION}

The presented data sets naturally contain a number of deficiencies which should not go unmentioned: The sampling procedure could not give a real "snapshot" of the North Sea, but covered a period of six weeks. One or two copepod generations may grow up in this time; other groups of organisms require shorter or longer times for their development. Therefore, it does not seem possible to define our distribution patterns as quasi synoptical pictures by means of mathematical methods. Furthermore, the determination of zooplankton-biomass was carried out with Formalin-fixed material. Nevertheless, several hints in the pertinent literature indicate that zooplankton samples treated with Formalin are subject to a weight loss of $20-40 \%$ (Krause \& Martens, 1990). Thus, we have to assume that the calculated load of cyclic organochlorines in the zooplankton represents a rather rough estimate, which nevertheless may give an impression of the dimensions of the examined pollutants incorporated in the drifting organisms.

\section{Distribution of pollutants in the North Sea zooplankton}

Based on our data, we may ascertain that - except for the Firth of Forth and the areas off the estuaries of Thames, Rhine and Elbe - the zooplankton stocks of the central and northern North Sea (north of $56^{\circ} \mathrm{N}$ ) generally contained clearly higher loads of cyclic organochlorines than the stocks of the southern North Sea, in spite of the fact that in the southern areas the highest concentrations of these pollutants were found in drifting animals by Knickmeyer \& Steinhart (1989a) and Knickmeyer (1990a). The large zooplankton stocks in the northern areas influenced by the Atlantic inflow are responsible for this fact. The high zooplankton-biomass suggests a considerable turnover of nutrients as well as of pollutants in the northern North Sea. 
Nutrient-rich Atlantic water spreads into the North Sea from the North in a leftturning way and offers excellent preconditions for a generous spring bloom of diatoms. Thus, the spring generation of Calanus finmarchicus, which drifts with the Atlantic currents from its overwintering areas into the shallow North Sea, finds excellent trophic conditions for building up enlarged summer stocks. In this process, considerable pollutants may enter the food chain. They could be transferred into the area by the atmosphere, by mixing with pure North Sea water, by the Atlantic water itself and by the inflow of mixed coastal and Atlantic waters coming from the Irish Sea.

Krause \& Martens (1990) indicate that the horizontal distribution patterns of zooplankton biomass imitated the cyclic current pattern of the Atlantic water. These centres of high biomass, which were formed almost entirely by Calanus (70-90\%), gradually shifted to deeper water layers forming a large left turning helix in the central and northern North Sea. This can be explained by interactions between hydrographic conditions and the particular behaviour of $C$. finmarchicus in its vertical migrations (Krause \& Radach, 1989; Krause \& Martens, 1990).

Based on these observations, it can be assumed that in the central and northern North Sea a considerable proportion of zooplankton stocks and their incorporated load of pollutants will be shifted into deeper layers and thus, finally, reach the sea floor. That may be the reason for the increased concentrations of mercury, cadmium and lead found in the hermit crab Pagurus bernhardus (Karbe et al., 1988) and in the sediment (Kersten \& Klatt, 1988; Sündermann \& Puls, 1990) just in this region of the North Sea.

With regard to the cyclic organochlorines, the vertical flux may be expressed, for example, through the PCB-patterns of the sediments. In the central North Sea low chlorinated congeners dominated, and these also predominated in the main groups of zooplankton like $C$. finmarchicus and Temora longicornis. On the other hand, higher chlorinated congeners, which originate from deposited suspended particulate matter, dominated in the sediments of the Kattegat, the Skagerrak, the Norwegian Trench and of the inner German Bight (Knickmeyer \& Steinhart, 1988, 1989b).

Knickmeyer (1990b) further points out that at various offshore stations the hermit crab $P$. bernhardus contained higher concentrations of sPCB's in late spring than in winter. In deeper water layers close to the sea floor, elevated contents of ammonia were also measured during the spring survey, evidence of the remineralization of organic nitrogen from the spring phytoplankton bloom (Brockmann, 1987). Knickmeyer (1989) assumes that the abundant sedimentation of dead organic material in late spring leads to an intensified vertical flux of low chlorinated PCB's into the benthal, where these substances will accumulate, particularly in Pagurus-eggs. On the other hand, during wintertime, when plankton stocks are low, no conspicuous quantities of low chlorinated PCB's could be found in those eggs. All these observations indicate that turnover processes in the plankton of the water column are of great importance for the determination of geographical distribution patterns of pollutants in the sediment as well as in the benthos organisms.

\section{Estimation of the total load of pollutants in the North Sea zooplankton}

Finally, with the considered data material the total content of zooplankton biomass in the North Sea as well as its load of cyclic organochlorines have been estimated: 
During late spring 1986, the total North Sea zooplankton content amounted to about 5 Mio $t(d w)$. The "Rat von Sachverständigen" (1980) stated an annual production of $50 \mathrm{~g} /$ $\mathrm{m}^{2}(\mathrm{dw})$ for herbivorous zooplankton in the entire North Sea. This implies about 29 Mio $\mathrm{t} / \mathrm{a}$, which means that in one year 5.8 times the biomass we found during spring 1986 (Table 1) is produced.

The zooplankton-biomass of nearly five million tons ( $\mathrm{dw}$ ) contained about $1.3 \mathrm{t}$ sPCB's. Nevertheless, this value has to be doubled to $2.6 \mathrm{t}$, because the determined congeners amounted to merely $50 \%$ of the ECD-signal. There follow p,p'-DDE with $19.3 \mathrm{~kg}, \tau-\mathrm{HCH}$ with $12 \mathrm{~kg}, \mathrm{HCB}$ with $6.4 \mathrm{~kg}$ and $\alpha-\mathrm{HCH}$ with $5.6 \mathrm{~kg}$ (Table 1). Assuming that zooplankton organisms have constant intake rates over all seasons, the annual turnover of measured cyclic organochlorines could be estimated by multiplying the pollutant load by the factor 5.8. According to this, the annual turnover would amount to $15.2 \mathrm{t}$ for PCB's, $111.8 \mathrm{~kg}$ for $\mathrm{p}_{\text {, }} \mathrm{p}^{\prime}-\mathrm{DDE}, 69.4 \mathrm{~kg}$ for $\tau-\mathrm{HCH}, 37.3 \mathrm{~kg}$ for $\mathrm{HCB}$ and $32.7 \mathrm{~kg}$ for $\alpha-\mathrm{HCH}$ (Table 1).

These findings are supported, for example, in the publication of Lohse (1988). He undertakes an estimation of the load of the considered pollutants in further compartments of the North Sea ecosystem in connection with an intensive study of the pertinent literature. Lohse's results are listed in Table 2. According to these, benthos-organisms and fish incorporate $1.6 \mathrm{t}$ and $1.8 \mathrm{t} \mathrm{PCBs}$, respectively. $\mathrm{HCB}$ came second with nearly $200 \mathrm{~kg}$, in both cases followed by $\tau-\mathrm{HCH}$ and $\alpha-\mathrm{HCH}$ with 50 and $30 \mathrm{~kg}$, respectively.

Lohse ascertains that water and sediment contain by far the heaviest load of measured pollutants (Table 2). Thus, at the most, $2 \%$ of $150 \mathrm{t}$ PCBs dissolved in North

Table 2. Estimation of the loads of cyclic organochlorines (tons) in diverse compartments of the North Sea (from Lohse, 1988)

\begin{tabular}{|lrrrrr|}
\hline Substance & Water & Sediment & Benthos & Fish & Total \\
\hline PCBs & 150 & 150 & 1.6 & 1.8 & 303.3 \\
Lindane & 65 & 20 & 0.05 & 0.03 & 85.1 \\
$\alpha-\mathrm{HCH}$ & 65 & 5 & 0.05 & 0.03 & 70.1 \\
HCB & 1.3 & 10 & 0.18 & 0.20 & 11.7 \\
\hline
\end{tabular}

Sea water were found again in zooplankton $(2.6 \mathrm{t})$. Furthermore, Lohse (1990) presents figures for the estimated annual inputs of pollutants into the North Sea (Table 3). According to these, all the PCBs entering the North Sea via rivers and atmosphere (= 6-13 t) have about the same order of magnitude as the annual turnover in zooplankton (= $15.2 \mathrm{t}$ ). On the other hand, $\mathrm{HCB}$ and $\tau-\mathrm{HCH}$ entering the North Sea in quantities of $1.2-3.2 \mathrm{t}$ and 3.5-6.5 tons, respectively, per annum would have an annual turnover lower by a factor 100 in zooplankton $(37.3 \mathrm{~kg}$ and $69.4 \mathrm{~kg})$.

Lohse $(1988,1990)$ points out that the spectrum of cyclic organochlorines (e.g. PCBs, $\mathrm{HCB}, \mathrm{DDT}, \tau-\mathrm{HCH}$ ), which nowadays can be measured in the marine ecosystem by elaborate techniques, has, for several years already, been recognized as dangerous and the discharge of these pollutants into the environment will decrease in the future. $\mathrm{He}$ assumes that these substances constitute, at the most, $5 \%$ of the absolute quantities of 
Table 3. Estimated annual inputs of cyclic organochlorines (tons) into the North Sea by rivers (from Lohse 1990) and by the atmosphere (from Gaul 1988)

\begin{tabular}{lcc|}
\hline Substance & Rivers & Atmosphere \\
\hline HCB & $1-3$ & 0.2 \\
Lindane & $2-5$ & 1.5 \\
PCBs & $3-10$ & 3.0 \\
Solvents & $200-500$ & - \\
I Adsorbable organochlorines & $5000-15000$ & - \\
\hline
\end{tabular}

organochlorines regularly released into the North Sea. Solvents alone account for 200-500 t entering the North Sea each year. During the same period, however, 5000-15000 tons of adsorbable organochlorines reach the North Sea via rivers (Table 3).

Acknowledgements. This work was funded by the German Minister for Research and Technology (project MFU 0545). Responsibility for the contents of this paper is with the authors. We thank the captain and the crew of R. V. Valdivia for their hospitality and co-operation. We appreciate very much the technical assistance of A. Bräutigam. Last but not least, we thank Mr. Horn (Bundesamt für Schiffahrt und Hydrographie) for producing the computer-made diagrams of the concentrations and loads of cyclic organochlorines in the North Sea.

\section{LITERATURE CITED}

Ballschmiter, K. \& Zell, M., 1980. Analysis of polychlorinated biphenyls (PCB) by glass capillary gas chromatography. - Fresenius Z. analyt. Chem. 302, 20-31.

Brockmann, U., 1987. Nährsalze und organische Substanzen. In: Zirkulation und Schadstoffumsatz in der Nordsee (ZISCH); BMFT-Projekt MFU 0545. 2. Zwischenbericht. Hrsg. von J. Sündermann \& S. Beddig. Univ. Hamburg, Hamburg, 150-166.

Carlson, H. (ed.), 1986. Quality status of the North Sea. - Dt. hydrogr. Z. (Erg.H. B) 16, 1-424.

Cushing, D. J., Humphrey, G. F., Banse, K. \& Laevastu, T., 1958. Report of the committee on terms and equivalents. - Rapp. P.-v. Réun. perm. int. Explor. Mer 144, 15-16.

Duinker, J. C., Hillebrand, M. T. J. \& Boon, J. P., 1983. Organochlorines in benthic invertebrates and sediments from the Dutch Wadden Sea: identification of individual PCB components. - Neth. J. Sea Res. 17, 19-38.

Gaul, H., 1988. Der Eintrag von Organohalogen-Verbindungen über die Atmosphäre in die Nordsee. - Dt. hydrogr. Z. 40, 221-224.

Gaul, H. \& Ziebarth, U., 1983. Method for the analysis of lipophilic compounds in water and results about the distribution of different organochlorine compounds in the North Sea. - Dt. hydrogr. Z. $36,191-212$.

Karbe, L., Gonzalez-Valero, J., Borchardt, T., Dembinski, M., Duch, A., Hablizel, H. \& Zeitner, R., 1988. Heavy metals in fish and benthic organisms from the northwestern, central and southern North Sea: Regional patterns comparing dab, blue mussel and hermit crab (Limanda limanda, Mytilus edulis, Pagurus bernhardus). - C. M. ICES, E22, 1-19.

Kersten, F. \& Klatt, V., 1988. Trace metal inventory and geochemistry of the North Sea shelf sediments. - Mitt. geol.-paläont. Inst. Univ. Hamburg 65, 289-311.

Knickmeyer, R., 1989. Cyclische Organohalogenide im benthischen Nahrungsnetz der Nordsee. Diss., Univ. Hamburg, $171 \mathrm{pp}$.

Knickmeyer, R., 1990a. Zooplankton-Kontamination mit chlorierten organischen Verbindungen. In: Warnsignale aus der Nordsee. Ed. by J. L. Lozán, W. Lenz, E. Rachor, B. Watermann \& H. v. Westernhagen. Parey, Berlin, 148-153. 
Knickmeyer, R., 1990b. Benthos: Kontamination mit chlorierten organischen Verbindungen. In: Warnsignale aus der Nordsee. Ed. by J. L. Lozán, W. Lenz, E. Rachor, B. Watermann \& H. v. Westernhagen. Parey, Berlin, 198-202.

Knickmeyer, R. \& Steinhart, H., 1988. The distribution of cyclic organochlorines in North Sea sediments. - Dt. hydrogr. Z. 41, 1-21.

Knickmeyer, R. \& Steinhart, H., 1989b. Cyclic organochlorines in North Sea sediments, relation with size and organic matter. - Dt. hydrogr. Z. 42, 43-59.

Knickmeyer, R. \& Steinhart, H., 1989a. Cyclic organochlorines in plankton from the North Sea in spring. - Estuar. coast. Shelf Sci. 28, 117-127.

Krause, M. \& Radach, G., 1989. On the relations of vertical distribution, diumal migration and nutritional state of herbivorous zooplankton in the northern North Sea during FLEX '76. - Int. Revue ges. Hydrobiol. 74, 371-417.

Krause, M. \& Martens, P., 1990. Distribution patterns of mesozooplankton biomass in the North Sea. - Helgoländer Meeresunters. 44, 295-327.

Lohse, J., 1988. Herkunft, Ausbreitung und Verteilung von schwerflüchtigen Chlorkohlenwasserstoffen in Sedimenten der Nordsee. Diss., Univ, Hamburg, 160 pp.

Lohse, J., 1990. Chlorierte organische Verbindungen in Wasser und Sediment. In: Warnsignale aus der Nordsee. Ed. by J. L. Lozán, W. Lenz, E. Rachor, B. Watermann \& H. v. Westernhagen. Parey, Berlin, 75-85.

Rat von Sachverständigen für Umweltfragen, 1980. Umweltprobleme der Nordsee. Sondergutachten Juni 1980. Kohlhammer, Stuttgart, 503 pp.

Sündermann, J. \& Puls, W., 1990. Modellarbeiten. In: Zirkulation und Schadstoffumsatz in der Nordsee (ZISCH II); BMFT-Projekt MFU 0545. Abschlußbericht. Hrsg. von J. Sündermann \& S. Beddig. Univ. Hamburg, Hamburg, 48-52. 